\title{
Life Cycle Assessment of energy flow and packaging use in food purchasing.
}

\author{
Esther Sanyé $^{1,2^{*}}$, Jordi Oliver-Solà ${ }^{1,2}$, Carles M. Gasol ${ }^{1,2}$, Ramon Farreny ${ }^{1,2}$, Joan \\ Rieradevall $^{1,3}$, Xavier Gabarrell ${ }^{1,3}$. \\ ${ }^{1}$ SosteniPrA (ICTA-IRTA-Inèdit)-Institut de Ciència i Tecnologia Ambientals (ICTA). Universitat \\ Autònoma de Barcelona. Campus de la UAB. 08193. Bellaterra (Barcelona), Spain. \\ ${ }^{2}$ Inèdit Innovació, S.L. Parc de Recerca de la Universitat Autònoma de Barcelona. Carretera de \\ Cabrils. Km2. 08348. Barcelona, Spain. \\ ${ }^{3}$ Departament d'Enginyeria Química (XRB). Universitat Autònoma de Barcelona. Campus de la \\ UAB. 08193. Bellaterra (Barcelona), Spain. \\ *Corresponding author: esther@ ineditinnova.com Tel: (+34) 937.532.915.
}

\begin{abstract}
The aim of this project is to obtain quantitative data on the metabolic flows (energy consumption, not only by the establishment but also in the transportation of workers and customers, and packaging use) and their resulting environmental impacts of a standard shopping basket purchase in five city-center municipal markets and a hypermarket in a suburban retail park in the province of Barcelona (Catalonia, Spain). The main results show that a standard shopping basket purchased in a retail park requires 20 times more energy than one purchased in a municipal market $(11.1 \mathrm{kWh}$ and $0.57 \mathrm{kWh}$, respectively). Customer transportation represents $83.2 \%$ of energy consumption in a retail park, while the greatest impacts in a municipal market stem from the establishment itself (49.5\%) and worker transportation (40.4\%). Secondly, the packaging use inventory is higher in a hypermarket $(253 \mathrm{~g})$ than in a municipal market $(102 \mathrm{~g})$. However, the overall environmental impact associated with a standard shopping basket is 10 times higher on average in a hypermarket than in a municipal market, and the carbon footprints of the hypermarket and the municipal market are 3.8 and $0.4 \mathrm{~kg}$ of $\mathrm{CO}_{2}$ eq., respectively. According to the sensitivity analysis, current policies for reducing the amount of plastic bag packaging have little repercussion in a retail park because its relative weight in terms of total packaging use is only 7\%. Nevertheless, they have notable effects in municipal markets where plastic bags represent $25 \%$ of the packaging use. Finally, if customers selected the least packaged products available in hypermarkets, each shopping basket could reduce up to $47.2 \%$ of its used packaging weight and between 15.4 and $59.0 \%$ of its associated environmental impact.
\end{abstract}

Keywords: agro-food retail, environmental impact, LCA, industrial ecology, carbon footprint, cities.

\section{Introduction}

The service sector carries the greatest economic weight in Western countries, represening approximately $70 \%$ of GDP (World Bank, 2008). Until now, the metabolic flows of this sector have not been thoroughly studied as they were assumed to be similar across types of services and of little importance to agricultural and industrial activities (Graedel, 1997). As a result, there has been environmental concern in these latter sectors, especially in the industrial area, and policies were generated in response, focusing mainly on air emissions and waste disposal (Graedel, 1997). This trend is justified as the dominant types of service-related activities have appeared to require less energy and materials than industry and agriculture (Heiskanen and Jalas, 2000), and this disconnection of economic growth from natural resource use, referred to as decoupling, has been associated with a lower environmental impact (Ayres and Ayres, 2001).

Furthermore, tertiarization in recent decades has increased energy and materials consumption of the service sector as well as their associated impacts. Nevertheless, these flows vary depending on the type of services (transport, tourism, catering, etc.), and a quantitative characterization of these flows can provide a qualitative view of the impacts associated with each type. According to the European Environmental Agency (2010), the service sector (excluding transport) represented $11.2 \%$ of the final energy consumption of the EU-27 in 2007 and $8.7 \%$ of greenhouse gas (GHG) emissions. Furthermore, the service sector has nearly the same energy intensity as the industrial sector (6.9 terajoules [TJ] compared with 8.4 TJ, taking in account the equivalent of 1 million Euros of GDP), according to Jespersen (1994), who analyzed the energetic intensity of more than 100 economic sectors (including heavy industry and the service sector) through input-output tables.

Finally, industrial ecology offers a different point of view to this kind of studies, given that the metabolic perspective 
considers the service sector from the point of view of traditional ecology and considers the service system as a system integrated in the biosphere (Erkman, 1997). Moreover, industrial ecology can study aspects of the service sector in depth, including factors that have not been taken into account in recent improvements that have been applied to the sector, such as the potential synergies among different parts of the system that is significant for services polygon formats (Farreny et al., 2009).

On the other hand, the food trade is one of the most important commercial branches of the service sector because it represents an essential service for a basic human need (Jones, 2002). Traditionally, there were municipal markets and small businesses that provided food services, but in recent decades, department stores and retail parks that provide food services have also appeared, extending a concept forged in North America in the 1930s and associated with the spread of car-based transportation in the 1960s to other continents (Escudero L.A., 2008). Western European estimates for 2006 suggested there were almost 1,400 hypermarkets selling food and several thousand selling non-food products concentrated in 700 retail parks (Guy, 2006).

According to Guy (1994), a retail park is a group of various retail outlets on one floor that typically includes a range of shopping chains (generally supermarkets as well as clothing, footwear, electrical and do-it-yourself material retailers) with large parking lots and proximity to major transport routes.

A municipal market can be defined as commercial equipment located in public spaces within the urban network where food can be purchased in stalls or small specialized shops of independent merchants.

In terms of income, commercial formats are distributed in the province of Barcelona (Generalitat de Catalunya, 2010a) among supermarkets $\left(400-2,500 \mathrm{~m}^{2}\right)(59 \%)$, super-services $\left(150-400 \mathrm{~m}^{2}\right)(12.7 \%)$, hypermarkets $(12 \%)$, boutiques $(11.2 \%)$, stores $(4 \%)$ and self-service $(1.2 \%)$. The commercial formats that are compared in this analysis concentrate on $23.2 \%$ of sector income and play a significant role. In addition, municipal trade facilities like municipal markets are associated with some other key roles in cities (Morales, 2009). First, markets are places that contribute to the quality of life and sociability of neighborhoods; second, public markets maintain a close relationship with urban planning; third, they also contribute to economic and social development; and, finally and most importantly for our purposes here, they play a role in addressing environmental concerns.

Food products have been the focus of several studies in recent decades. The food industry is one of the world's largest industrial sectors, and it uses a great amount of energy. Agricultural production has been indicated as a hotspot in the life cycle of food products (Poritosh et al., 2009). Using the life cycle assessment methodology, the production stage has been analyzed for industrial food products, including: tomato ketchup (Andersson et al., 1998) and dairy and meat production (Berlin et al., 2007), and agricultural products, such as tomatoes (Antón et al, 2005). Moreover, the research on agricultural production has also focused on raw materials and waste management (Martínez et al., 2009, 2011; Muñoz et al., 2004), as well as on cultivation methodologies to improve the environmental profile of crops, such as organic farming (Cederberg and Mattsson, 2000; Meisterling et al., 2009). Besides, the introduction of good practices in food industry were also analyzed, highlighting waste minimization (Henningsson et al., 2004; Hyde et al., 2001) and food waste management (Lundie and Peters, 2005).

Recently, the packaging of food products has been studied as a product (taking into account their production, materials and waste) (Ross and Evans, 2003; Zabaniotou and Kassidi, 2003) and as part of the food product cycle, such as beer (Koroneos et al., 2005).

Regarding the distribution stage, some studies have quantified the energy consumption and environmental impact related to the overall food supply chain (Jones, 2002) as well as the differences between local and imported products (Milà i Canals et al., 2007).

Although retail has been included in the life cycle of food products in some studies when defined as food consumption (Jungbluth et al., 2000), it only includes customer transportation and food preparation and cooking. Several significant factors have been omitted, and these omissions highlight the need for including the food retail facility and its workers in an environmental performance analysis of a food purchase.

In this context, the aim of this study is to quantify the overall environmental impact associated with energy consumption and packaging use of a standard purchase in two types of commercial facilities. Moreover, quantitative data can support the decision-making process in food retail, not only from the customers' point of view but also from the manager's one.

\section{Methodology}

This paper focuses its analysis on those food product life cycle stages that are related to retail. More specifically, the study focuses on the energy consumption and on the packaging use vectors (Figure 1), excluding food transportation to retail and other minor vectors such as water consumption. The study works in two phases: the quantification of vector flows on the basis of a Material and Energy Flow Analysis (MEFA) (Haberl et al., 2004) and the quantification of associated impact by means of a Life Cycle Assessment (LCA) (ISO 14040, 2006). 


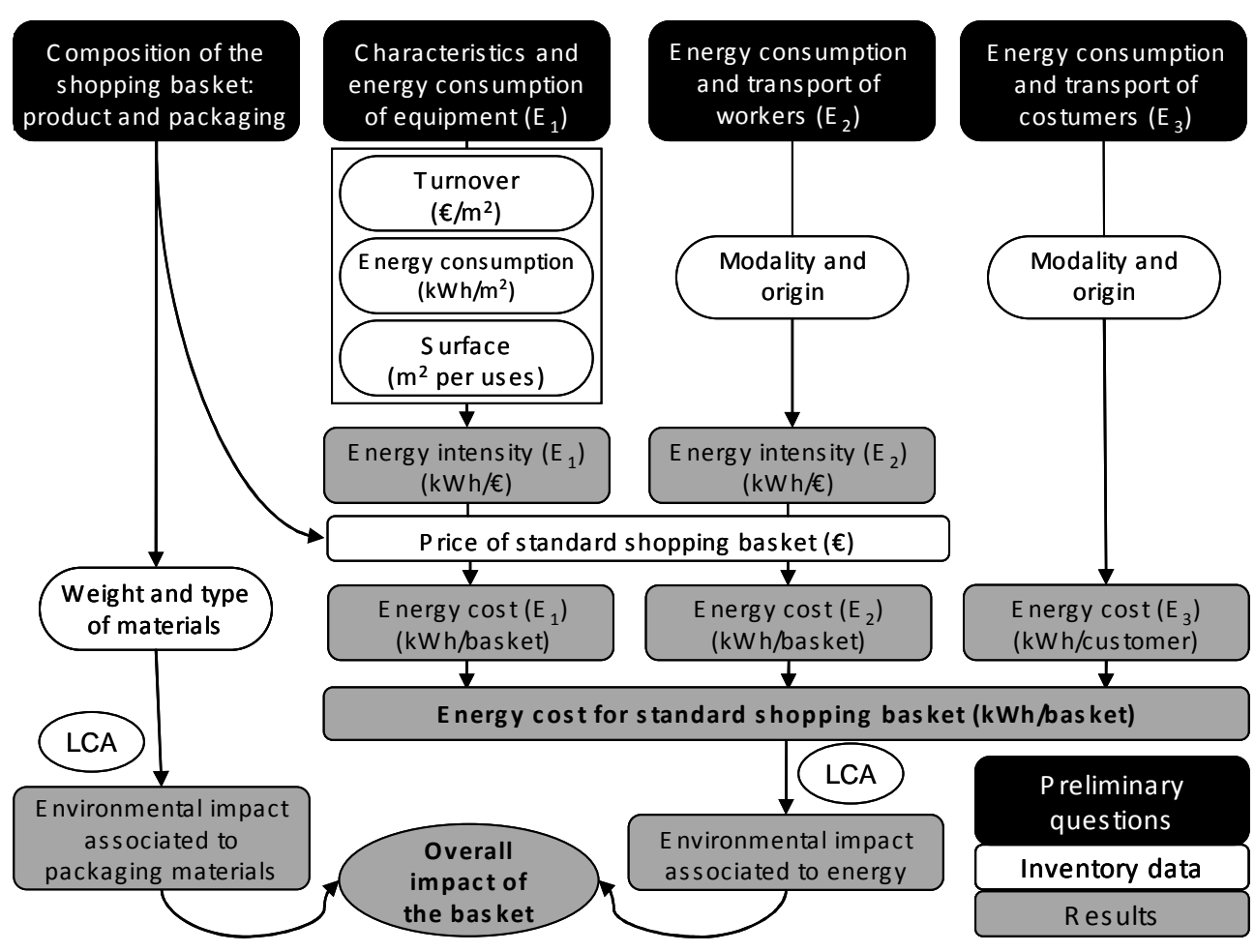

\subsection{Study System}

The analysis was performed in two typologies of food retail stores representative of the sector and with different social and environmental characteristics. The study area is the province of Barcelona, Catalonia, in northeastern Spain.

For the municipal market typology, five markets were chosen and the average data was used. They are representative of different types of municipal markets as they present differences in the pattern of energy consumption (heating, ventilation and air conditioning systems) and in the availability of free parking areas, which conditions motorized access. No quantitative studies had been performed previously in these markets (Table 1).

For the hypermarket typology, a hypermarket in a retail park was chosen. This is located outside compact urban areas and closely linked to a motorway, being representative of this type of commercial format in Europe. It has free parking for 4,000 private vehicles and includes nine single-floored buildings, of which the largest and most representative includes the hypermarket (Farreny et al., 2008) (Table 1).

Table 1. City population, store characteristics, turnover and shopping basket price for the different stores analyzed.

\begin{tabular}{|c|c|c|c|c|c|c|}
\hline & \multirow{3}{*}{$\begin{array}{c}\text { Hypermarket } \\
\text { Sant Boi del } \\
\text { Llobregat }\end{array}$} & \multicolumn{5}{|c|}{ Municipal markets } \\
\hline & & \multirow{2}{*}{$\begin{array}{c}\text { Sant Boi del } \\
\text { Llobregat }\end{array}$} & \multirow{2}{*}{ Olesa } & \multirow{2}{*}{ Castellar } & \multicolumn{2}{|c|}{ Cerdanyola } \\
\hline & & & & & Serraparera & Fontetes \\
\hline Population $^{1}$ & 82,411 & 82,411 & 23,646 & 23,129 & \multicolumn{2}{|c|}{58,407} \\
\hline Total surface $\left(\mathrm{m}^{2}\right)$ & 300,000 & $7,276.32$ & 3,290 & 1,690 & $3,527.67$ & $2,344.68$ \\
\hline Retail surface $\left(\mathrm{m}^{2}\right)$ & 26,000 & $1,922.32$ & 660 & 160 & 166.16 & 829.02 \\
\hline Workers & 600 & 64 & 83 & 29 & 60 & 40 \\
\hline Ratio (Worker/100m²) & 2.3 & 3.33 & 12.58 & 10.51 & 6.02 & 4.83 \\
\hline Work schedule (h/week) & 72 & 57 & 52 & 46.5 & 42.5 & 42.5 \\
\hline Turnover $\left(€ / \mathrm{m}^{2}\right)^{2}$ & $5,570.80$ & $2,464.40$ & $2,189.70$ & $1,797.80$ & $2,380.50$ & $3,830.80$ \\
\hline Shopping basket cost $(€)^{3}$ & 27.02 & & & 33.57 & & \\
\hline
\end{tabular}

${ }^{T}$ IDESCAT (2001); ${ }^{2}$ Estimation based on the data of annual average turnover per surface of shop $\left(\mathrm{m}^{2}\right)$ by kind of shop, from Diputació de Barcelona(DIBA) (2007), and the surface of each municipal market, available in Generalitat de Catalunya (2010b); ${ }^{3}$ Field work data. 


\subsection{Functional unit}

For comparative purposes, a standard shopping basket was defined as the functional unit. For the goal of this study, the standard shopping basket contains: $150 \mathrm{~g}$ lean meat, $400 \mathrm{~g}$ minced meat, $125 \mathrm{~g}$ boiled ham, $125 \mathrm{~g}$ cheese, 6 eggs, $250 \mathrm{~g}$ sliced cod, $500 \mathrm{~g}$ clams, 4 apples, 3 courgettes, $300 \mathrm{~g}$ green beans, $1 \mathrm{~kg}$ potatoes and $90 \mathrm{~g}$ almonds.

This basket was determined on the basis of the Consumer Price Index (CPI) of the Spanish National Statistics Institute (INE) and on the Continuous Survey of Family Budgets (ECPF). Moreover, the product quantity was determined according to a balanced 2,300 kcal diet as established in Pinto and Carbajal (2003), and specific product quantities were chosen to avoid those only available in packs of certain units or quantities in a retail park.

\subsection{Material and Energy Flow Analysis}

\subsubsection{Energy consumption}

The energy cost of the standard shopping basket ( $\mathrm{kWh} /$ basket) was quantified in three stages: the energetic consumption of the establishment, worker transportation and customer transportation. For the establishment and the worker transportation consumption, data was quantified in turnover terms $(\mathrm{kWh} / €)$ and extrapolated for the price of the standard shopping basket $(€)$. For customer transport, the energy cost is the energy consumption by one customer, as each purchase is made for one group of customers (Figure 1).

Given that municipal market systems are aggregations of small stalls, each with its own data, the data collection procedure for these systems was complex due to data atomization. This fact makes it difficult to collect accurate data of energy consumption and annual turnover; thus, this paper estimated some data using surveys.

\subsubsection{Establishment}

Establishment energy intensity $(\mathrm{kWh} / €)$ was obtained from the electrical invoice for the hypermarket. Data source for the hypermarket was the establishment itself, including the proportion of electrical energy consumption (kWh) over turnover $(€)$ for 2006. In economic terms, energy intensity (1) for the municipal market system was estimated using the installed power and the establishment weekly schedule (Diputació de Barcelona, 2009).

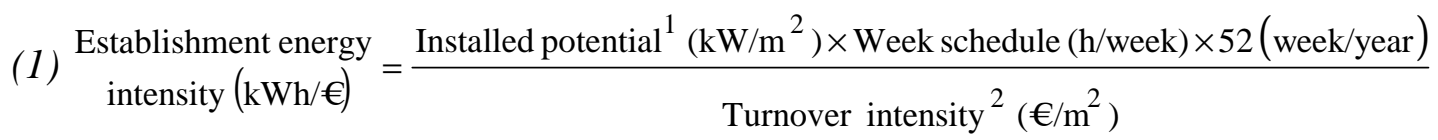

${ }^{I} 8 \mathrm{~W} / \mathrm{m}^{2}$ is considered from Diputació de Barcelona (2009), where calculations were done for municipal markets with an installed potential between 6 to $10 \mathrm{~W} / \mathrm{m}^{2}$.

${ }^{2}$ Estimation based on the data of annual average turnover per surface of shop $\left(\mathrm{m}^{2}\right)$ by kind of store from Diputació de Barcelona (2007) and the surface of each municipal market (Generalitat de Catalunya, 2010b).

\subsubsection{Transport}

Transport of workers and customers was measured using the methodology shown in Farreny et al. (2008) with some adjustments. Calculations were made by estimating the total distance covered using the work movement pattern and trip distance (Table 2). For the fuel consumption estimation, the average motorized distance $\left(\mathrm{D}_{\mathrm{m}}\right)(2)$ was obtained using 276 working days per year, the total number of workers $(\mathrm{T})$ and the trips taken in the same municipality $\left(\mathrm{X}_{\mathrm{w}}\right)$, including the walking modality $\left(\%_{\mathrm{w}}\right)$. Finally, the transportation consumption for workers $(3)$ and customers (4) were calculated using the distribution of the fleet of vehicles by fuel type (INE, 2009), the occupancy for private and public vehicles, the efficiency for transport and fuel typology and the TOE conversion (GHG Protocol Initiative, 2005) (Table 3).

$$
D_{m}=276 \cdot T \cdot 2 \cdot\left(X-\%_{w} \cdot X_{w}\right)
$$

$\begin{aligned} & \text { (3) Energy intensity of } \\ & \text { workers transport }(\mathrm{kWh} / €)\end{aligned}=\frac{\text { (Public transport consumption }+ \text { Private transport consumption })(\mathrm{TOE}) \times 11,620(\mathrm{kWh} / \mathrm{TOE})}{\text { Establishment surface }\left(\mathrm{m}^{2}\right) \times \operatorname{Turnover}^{2}\left(€ / \mathrm{m}^{2}\right)}$

(4) Energy intensity of $\begin{aligned} & \text { Energy intensity of } \\ & \text { customer transport }(\mathrm{kWh} / \text { customer })\end{aligned}=($ Public transport consumption + Private transport consumption $)(\mathrm{TOE}) \times 11,620(\mathrm{kWh} / \mathrm{TOE})$ 


$$
\begin{gathered}
\text { Private transport } \\
\text { consumption }(\mathrm{TOE})
\end{gathered}=\frac{\mathrm{D}_{\mathrm{m}} \cdot \%_{\mathrm{pr}}(\mathrm{km})}{\mathrm{o}_{2}} \cdot\left(\frac{\%_{\text {diesel }}}{e_{1}(\mathrm{~km} / \mathrm{L}) \times c_{1}(\mathrm{~L} / \mathrm{TOE})}+\frac{\%_{\text {gasoline }}}{e_{2}(\mathrm{~km} / \mathrm{L}) \times c_{2}(\mathrm{~L} / \mathrm{TOE})}\right)
$$

154

Table 2. Average distance and modality for workers and customers transport, by food store type.

\begin{tabular}{|c|c|c|c|c|}
\hline & \multicolumn{2}{|r|}{ Workers $^{1}$} & \multicolumn{2}{|r|}{ Customers $^{2}$} \\
\hline & $\begin{array}{c}\text { Average } \\
\text { distance }(\mathbf{k m})\end{array}$ & Modality & $\begin{array}{c}\text { Average } \\
\text { distance }(\mathbf{k m})\end{array}$ & Modality \\
\hline $\begin{array}{c}\text { Retail } \\
\text { park }\end{array}$ & $5 \mathrm{~km}$ & $\begin{array}{c}\text { Walking }\left(\%_{w}\right)=21 \% \\
\text { Private vehicle }\left(\%_{p r}\right)=65 \% \\
\text { Public transport }\left(\%_{p u}\right)=14 \%\end{array}$ & $7.3 \mathrm{~km}$ & $\begin{array}{c}\text { Walking }\left(\%_{w}\right)=0 \% \\
\text { Private vehicle }\left(\%_{p r}\right)=99 \% \\
\text { Public transport }\left(\%_{p u}\right)=1 \%\end{array}$ \\
\hline $\begin{array}{c}\text { Municipal } \\
\text { markets }\end{array}$ & $4.3 \mathrm{~km}$ & $\begin{array}{c}\text { Walking }\left(\%_{w}\right)=58 \% \\
\text { Private vehicle }\left(\%_{p r}\right)=21 \% \\
\text { Public transport }\left(\%_{p u}\right)=21 \%\end{array}$ & $1 \mathrm{~km}$ & $\begin{array}{c}\text { Walking }\left(\%_{w}\right)=90 \% \\
\text { Private vehicle }\left(\%_{p r}\right)=2 \% \\
\text { Public transport }\left(\%_{p u}\right)=8 \%\end{array}$ \\
\hline
\end{tabular}

${ }^{1}$ IDESCAT, 2001- Labor mobility statistics, by municipality; ${ }^{2}$ Market study for retail park data, and municipal market managers for municipal markets.

Table 3. Summary of vehicle energy efficiencies, conversion factors, distribution by type of fuel in the Spanish private vehicle park and occupancy.

\begin{tabular}{|c|c|c|c|c|c|}
\hline \multirow{2}{*}{ Vehicle } & \multirow{2}{*}{$\begin{array}{c}\text { Efficiency }{ }^{1} \\
(\mathrm{~km} / \mathrm{L})\end{array}$} & \multirow{2}{*}{$\begin{array}{c}\text { Conversion to } \text { TOE }^{1} \\
(\mathrm{~L} / \mathrm{TOE})\end{array}$} & \multicolumn{2}{|c|}{ National private vehicle park ${ }^{2}$} & \multirow{2}{*}{ Occupancy $^{3}$} \\
\hline & & & Number & $\%$ & \\
\hline Diesel auto & $10.20\left(\mathrm{e}_{1}\right)$ & $1150\left(c_{1}\right)$ & $1,902,138$ & $57 \%$ & $1.56\left(\mathrm{o}_{1}\right)$ \\
\hline Gasoline auto & $9.34\left(e_{2}\right)$ & $1250\left(c_{2}\right)$ & $1,430,386$ & $43 \%$ & $1.56\left(\mathrm{o}_{1}\right)$ \\
\hline Diesel bus & $2.85\left(e_{3}\right)$ & $1150\left(\mathrm{e}_{3}\right)$ & - & & $20\left(\mathrm{o}_{2}\right)$ \\
\hline
\end{tabular}

${ }^{I}$ The average efficiency used is for typical vehicles based on averages from US EPA 2001 Guide (GHG Protocol Initiative, 2005); ${ }^{2}$ INE, 2009; ${ }^{3}$ Farreny et al., 2008.

\subsubsection{Packaging vector}

The quantity and type of packaging materials of the standard purchase were quantified, sorting the primary product packaging and plastic bags used by customers to transport the basket home. The shopping basket designed was done in a municipal market and in a hypermarket of the study area. The purchase was done in the same city to avoid geographic cost differences. The packaging of each product was sorted, weighted using analytical scales and categorized by type of material for each type of commercial establishment to perform the environmental impact analysis.

\subsection{Sensitivity analysis}

The study includes a sensitivity analysis for the packaging vector (A and B) and for the energy vector (C):

- Scenario A: the removing of LDPE bags was evaluated assuming that they are replaced by a shopping trolley;

- Scenario B: the least packed options for hypermarket products are accounted; and

- Scenario C: the quantification of sustainable mobility policies for hypermarket customers was done assuming the same modality as the municipal market users ( $80 \%$ public transport and $20 \%$ private vehicle).

\subsection{Environmental tools: Life cycle assessment (LCA) and Data quality}

Once the energy and packaging flows were quantified, the LCA methodology (ISO 2006) was applied to classify and characterize the environmental impacts for different categories. Classification enabled each environmental load to be sorted into one or more impact categories, and characterization allowed the calculation of the overall impact by multiplying each load by a factor associated with each impact category. The classification and characterization stages observed the CML 2 Baseline (Guinée et al. 2001) methodology. The selected midpoint impact potentials and their units are abiotic depletion ( $\mathrm{kg} \mathrm{Sb}$-eq.), acidification ( $\mathrm{kg} \mathrm{SO}_{2}$-eq.), eutrophication ( $\mathrm{kg} \mathrm{PO}_{4}{ }^{3--}$ eq.), global warming $\left(\mathrm{kg} \mathrm{CO}_{2}\right.$ eq.), ozone layer depletion (kg CFC-11-eq.) and human toxicity (kg 1.4-DB-eq.).

Background data for the inventory was obtained from the Ecoinvent 2.0 database for the energy production of energy flows (electric and fossil fuels) (Dones et al., 2007) and the materials of the inventoried packaging flow (Hischier, 2007). For the packaging vector, the life cycle stages taken into account in the LCA were the extraction of the raw materials, the transportation and its processing; other stages, such as waste management, were excluded in the analysis. Foreground data includes the amount and typology of materials for the packaging use and the energy consumption (electricity and fuel) for the establishment and the transportation of workers and customers. 


\section{Results and discussion}

\subsection{Energy consumption}

The energy consumption of a standard shopping basket (Table 4) is higher for a food purchase in a hypermarket (11.10 $\mathrm{kWh})$ than in a municipal market $(0.57 \mathrm{kWh})$ with a ratio of 20 to 1 . Customer transportation is the main contribution to it for the retail park, with a higher motorized distance and a motorized share. The customer transport ratio between the two establishments is 160 to 1 and indicates the greatest divergence between the two systems. If this stage was excluded from the analysis, the ratio would be reduced to 5 to 1 . This result agrees with Morales (2009), which states that municipal markets play a role in addressing environmental concerns as they reduce distance travelled by vehicles. Due to a lower ratio of workers per surface in municipal markets, worker transportation is the only stage that has a higher energy cost for municipal markets than for the hypermarket (Table 4). Thus, by analyzing the characteristics of each stage of consumption, the inequalities between the types of establishment are observed (Table 5).

According to the energy consumption patterns observed, the customers distance and the establishment consumption are the key points. For one site, municipal markets are situated in city centers and the avoided customer transport is a environmental benefit compared to retail parks. However, municipal markets showed that environmental strategies should focused on the establishment's energy efficiency.

Table 4. Inventory results for energy vector.

\begin{tabular}{ccccc}
\hline & \multicolumn{4}{c}{ Energy consumption (kWh/basket) } \\
\hline & Facility & Worker transportation & Customer transportation & TOTAL \\
\hline Hypermarket in a & 1.68 & 0.18 & 9.23 & $\mathbf{1 1 . 1}$ \\
retail park (RP) & 0.28 & 0.23 & 0.06 & $\mathbf{0 . 5 7}$ \\
Municipal market (M) & 6 & 0.8 & 160 & $\mathbf{1 9 . 5}$ \\
RP/M ratio & 6 &
\end{tabular}

Table 5. Characteristics of each establishment, by consumption stage

\begin{tabular}{cccc}
\hline & Establishment & Transport of workers & Transport of customers \\
\hline $\begin{array}{c}\text { Hypermarket } \\
\text { in a retail } \\
\text { park }\end{array}$ & $\begin{array}{c}\text { Greater number of } \\
\text { high power equipment } \\
\text { installed (air }\end{array}$ & $\begin{array}{c}\text { Higher average distance }(5 \mathrm{~km}) \\
\text { Motorization: } 79 \%\end{array}$ & $\begin{array}{c}\text { Supramunicipal influence } \\
\text { Higher establishment-home distance } \\
(7.3 \mathrm{~km})\end{array}$ \\
& $\begin{array}{c}\text { conditioning, } \\
\text { refrigeration) }\end{array}$ & $\begin{array}{c}\text { lower ratio of workers per } \mathrm{m}^{2}, \text { which } \\
\text { reduces unitary consumption }(\mathrm{kWh} / €)\end{array}$ & $\begin{array}{c}\text { Motorization: } 100 \% \\
\text { Lower use of public transport }(1 \%)\end{array}$ \\
$\begin{array}{c}\text { Municipal } \\
\text { market }\end{array}$ & $\begin{array}{c}\text { Lower number of high } \\
\text { power equipment }\end{array}$ & Lower average distance $(3.4 \mathrm{~km})$ & Municipal influence \\
& installed & Motorization: $42 \%$ & Lower average distance $(0.8 \mathrm{~km})$ \\
& Higher cost of basket, which leads to & Motorization: $10 \%$ \\
higher total consumption $(\mathrm{kWh} / \mathrm{basket})$ & Greater use of public transport $(8 \%)$ \\
\hline
\end{tabular}

\subsection{Packaging vector}

Packaging use is also higher in a retail park (253 g) than in a municipal market $(102 \mathrm{~g})$. However, the distribution between primary packaging and plastic bags and the type of materials used are different in each establishment (Table 6). Primary packaging is more relevant $(93 \%)$ in hypermarkets, where product positioning promotes easy and rapid acquisition by customers and means that products tend to be overpackaged. In contrast, plastic bags have a greater role in municipal markets ( $25 \%$ by weight) as a consequence of their lower optimization because one is given per stall.

The materials used in the manufacture of trays (PS, PP, HDPE), multilayer packaging (PET) and casing for other packaging (cardboard) is not generated, or these materials are generated in much smaller quantities at a municipal market because this kind of packaging is not characteristic of such establishments.

Regarding the shopping basket components, packaging for meat products and for vegetables were different for both retails. However, products in the hypermarket showed a higher material intensity due to their overpacking. Therefore, even with changes in the shopping basket, a less packaging amount is obtained in purchases done in municipal markets as the bulk shopping represents a monomaterial and light packaging for food products.

Table 6. Inventory data for packaging vector, by system, material and typology of packaging.

\begin{tabular}{lcccc}
\hline & & $\begin{array}{c}\text { Hypermarket in a } \\
\text { retail park (RP) }\end{array}$ & Municipal market (M) & RP/M ratio \\
\hline Primary packaging & & $\mathbf{2 3 5 . 0} \mathrm{g}$ & $\mathbf{7 6 . 6} \mathrm{g}$ & $\mathbf{3 . 0}$ \\
Plastics & Low Density Polyethylene (LDPE) & $16.7 \mathrm{~g}$ & $22.2 \mathrm{~g}$ &
\end{tabular}




\begin{tabular}{llcc} 
& Polystyrene (PS) & $92.7 \mathrm{~g}$ & $3.8 \mathrm{~g}$ \\
& Polypropylene (PP) & $14.6 \mathrm{~g}$ & $10 \mathrm{~g}$ \\
& Ethylene Propylene Diene Monomer & $0.4 \mathrm{~g}$ & $0.7 \mathrm{~g}$ \\
& rubber (EPDM) & $59.1 \mathrm{~g}$ & 0 \\
& High density Polystyrene (HDPE) & $21.6 \mathrm{~g}$ & 0 \\
\hline Others & Polyethylene terephthalate (PET) & 0 & $20.2 \mathrm{~g}$ \\
& Waxed paper & 0 & $19.9 \mathrm{~g}$ \\
\hline Plastic bags & Recycled cardboard & $29.9 \mathrm{~g}$ & 0 \\
\hline TOTAL & Lardboard & $\mathbf{1 7 . 9} \mathbf{g}$ & $\mathbf{2 5 . 5} \mathbf{~ g}$ \\
\hline
\end{tabular}

\subsection{Environmental impact}

The environmental impact associated to a standard shopping basket is higher for a hypermarket in a retail park than for a municipal market by a ratio of 7-18 to 1, depending on the different categories. The environmental impact associated with the transport of customers is more divergent, between 75 and 233 times higher in a retail park depending on the category analyzed (Table 7).

The impact associated with packaging use is lower for a municipal market, representing between $22 \%$ and $48 \%$ of the impact in hypermarkets, depending on the impact category (Table 7). The use of packaging (in weight) in hypermarkets is 2.5 times greater than that of municipal markets, and materials with a greater impact per kg (PS, PET and cardboard) are found in much higher quantities in hypermarkets.

The overall impact of the shopping basket (Table 5) is between 6 and 18 times higher in a hypermarket, depending on the category analyzed. Differentiating between the two vectors of the study, between 70 and $95 \%$ of the overall impact in a hypermarket in a retail park is associated with energy consumption, while the distribution between vectors is more even in municipal markets where the packaging vector represents between 25 and $62 \%$.

Table 7. Environmental impact of one standard shopping basket by impact category, commercial establishment and 250 vector.

\begin{tabular}{|c|c|c|c|c|c|c|}
\hline Retail park (1 & $\begin{array}{c}\text { Abiotic } \\
\text { depletion } \\
\text { (kg Sb-eq) }\end{array}$ & $\begin{array}{l}\text { Acidification } \\
\left(\mathrm{kg} \mathrm{SO}_{2} \text {-eq }\right)\end{array}$ & $\begin{array}{c}\text { Eutrophication } \\
\qquad\left(\mathrm{kg} \mathrm{PO}_{4}{ }^{3-} \mathrm{eq}\right)\end{array}$ & $\begin{array}{c}\text { Global warming } \\
\text { potential } \\
\left(\mathrm{kg} \mathrm{CO}_{2} \text {-eq }\right)\end{array}$ & $\begin{array}{c}\begin{array}{c}\text { Ozone layer } \\
\text { depletion }\end{array} \\
\text { (kg CFC-11-eq) }\end{array}$ & $\begin{array}{c}\begin{array}{c}\text { Human } \\
\text { toxicity }\end{array} \\
(\mathrm{kg} 1,4-\mathrm{DB}-\mathrm{eq})\end{array}$ \\
\hline Energy & $2.05 \mathrm{E}-02$ & $1.34 \mathrm{E}-02$ & $1.26 \mathrm{E}-03$ & $3.07 \mathrm{E}+00$ & $3.65 \mathrm{E}-07$ & 7.39E-01 \\
\hline Packaging & $8.92 \mathrm{E}-03$ & $2.37 \mathrm{E}-03$ & $3.21 \mathrm{E}-04$ & 7.27E-01 & $1.14 \mathrm{E}-08$ & $1.14 \mathrm{E}-01$ \\
\hline Total & 2.94E-02 & $1.58 \mathrm{E}-02$ & $1.58 \mathrm{E}-03$ & $3.80 \mathrm{E}+00$ & 3.76E-07 & 8.53E-01 \\
\hline \multicolumn{7}{|c|}{ Municipal market $(M)$} \\
\hline Energy & $1.73 \mathrm{E}-03$ & $1.91 \mathrm{E}-03$ & $1.38 \mathrm{E}-04$ & $2.46 \mathrm{E}-01$ & 2.02E-08 & $6.51 \mathrm{E}-02$ \\
\hline Packaging & $2.50 \mathrm{E}-03$ & 7.43E-04 & $9.25 \mathrm{E}-05$ & $2.20 \mathrm{E}-01$ & $5.29 \mathrm{E}-09$ & $2.80 \mathrm{E}-02$ \\
\hline Total & 4.23E-03 & 2.53E-03 & 2.08E-04 & 4.46E- 01 & 2.08E-08 & 8.73E-02 \\
\hline \multicolumn{7}{|l|}{ RP/M Ratio } \\
\hline Energy & 11.9 & 7.0 & 9.1 & 12.5 & 18.2 & 11.4 \\
\hline Packaging & 3.6 & 3.2 & 3.5 & 3.3 & 2.2 & 4.1 \\
\hline Total & 7.3 & 6.2 & 7.6 & 8.8 & 18.1 & 9.8 \\
\hline
\end{tabular}

251 Source: Authors of SimaPro V.7.2 and CML 2000 Methodology

252 Note: eq=equivalents, $\mathrm{Sb}=$ antimony, $\mathrm{SO}_{2}=$ sulfur dioxide, $\mathrm{PO}_{4}{ }^{3-}=$ phosphate, $\mathrm{CO}_{2}=$ carbon dioxide,

253 CFC-11=chlorofluorocarbons, 1,4-DB=1,4-dibuthyl.

The environmental profile shows that the impact categories have the same pattern, except for Ozone Layer Depletion Potential (ODP). However, in the context of global environmental awareness and particularly with regard to GHG emissions, Global Warming Potential (GWP) requires more attention.

In the systems defined in this study, the GWP related to energy consumption and packaging of a standard shopping basket is $3.80 \mathrm{~kg} \mathrm{CO}_{2}$-eq. for a retail park and $0.47 \mathrm{~kg} \mathrm{CO}_{2}$-eq. for a municipal market. This impact category points to differences observed between the weights of each vector depending on the type of establishment: the energy vector represents $81 \%$ in a retail park versus $55 \%$ in a municipal market.

The results showed that the environmental policies in food retail depend on the store type. Municipal markets should focus on the energy consumption of the establishment and to be energy efficient. Moreover, bulk shopping showed less environmental impact for packaging, but common bags for the overall market (and not one by store) could optimize the 
secondary packaging use.

On the other hand, the distance between city centers and retails parks represent the hotspot in the environmental impact associated to a shopping basket done in a hypermarket. Establishments nearer the city center and public transport for customers would be effective environmental policies.

\subsection{Sensitivity analysis}

\subsubsection{Scenario A: LDPE-bag removal in both systems}

In terms of weight, there was a $7 \%$ reduction of the packaging use in the hypermarket and $25 \%$ in municipal markets when LDPE bags were removed from each system. Accordingly, the environmental impact decrease for the packaging vector shows the same trend; for a hypermarket, the impact was 0.04\%-6.6\% lower in this scenario for the different categories, and for the municipal market, the reduction of $0.1 \%-33.9 \%$ shows higher impacts (Table 5 and 6 ).

This sensitivity analysis indicates that this proposal has a higher effect in municipal markets than in hypermarkets due to the fact that consumer packaging represents a higher percentage of all packaging in the municipal market system.

As a result, the potential impact for the packaging use in hypermarkets remains higher than the municipal market system by a ratio of 2.1-5 to 1 .

\subsubsection{Scenario B: Primary packaging reduction in the hypermarket shopping basket}

The total amount of packaging was reduced to $47 \%$ of weight $(170 \mathrm{~g})$ by choosing products with less packaging, an attribute that also varies the material composition.

This primary packaging for the hypermarket saved $15.4 \%-59 \%$ in the different categories of environmental impact, excluding ODP, which increased by $4.4 \%$ compared to the baseline scenario (Table 8).

Unless this scenario shows an improvement of the environmental profile, the potential impact of the packaging vector for the hypermarket remains higher than for the municipal market system in all of the categories analyzed at a rate of 1.5-3.5 to 1 across the different categories (Table 8).

Table 8. Environmental impacts of one standard shopping basket related to the packaging vector for scenarios 0 , A and $B$, by category of impact, commercial establishment and environmental vector.

\begin{tabular}{|c|c|c|c|c|c|c|}
\hline & $\begin{array}{c}\text { Abiotic } \\
\text { depletion } \\
(\mathrm{kg} \mathrm{Sb} \mathrm{eq})\end{array}$ & $\begin{array}{l}\text { Acidification } \\
\left(\mathrm{kg} \mathrm{SO}_{2} \mathrm{eq}\right)\end{array}$ & $\begin{array}{l}\text { Eutrophication } \\
\qquad\left(\mathrm{kg} \mathrm{PO}_{4}{ }^{3-} \mathrm{eq}\right)\end{array}$ & $\begin{array}{c}\text { Global warming } \\
\text { potential } \\
\left(\mathrm{kg} \mathrm{CO}_{2} \mathrm{eq}\right)\end{array}$ & $\begin{array}{c}\text { Ozone layer } \\
\text { depletion } \\
\text { (kg CFC-11 eq) }\end{array}$ & $\begin{array}{c}\begin{array}{c}\text { Human } \\
\text { toxicity }\end{array} \\
(\mathrm{kg} 1,4-\mathrm{DB} \text { eq })\end{array}$ \\
\hline \multicolumn{7}{|l|}{ Scenario 0 } \\
\hline \multirow{2}{*}{$\begin{array}{l}\text { Retail park } \\
\text { Municipal } \\
\text { market }\end{array}$} & $8.92 \mathrm{E}-03$ & $2.37 \mathrm{E}-03$ & $3.21 \mathrm{E}-04$ & $7.27 \mathrm{E}-01$ & $1.14 \mathrm{E}-08$ & $1.14 \mathrm{E}-01$ \\
\hline & $2.50 \mathrm{E}-03$ & 7.43E-04 & $9.25 \mathrm{E}-05$ & $2.20 \mathrm{E}-01$ & 5.29E-09 & $2.80 \mathrm{E}-02$ \\
\hline RP/M Ratio & 3.6 & 3.2 & 3.5 & 3.3 & 1.9 & 4.1 \\
\hline \multicolumn{7}{|l|}{ Scenario A } \\
\hline \multirow{2}{*}{$\begin{array}{l}\text { Retail park } \\
\text { Municipal } \\
\text { market }\end{array}$} & $8.32 \mathrm{E}-03$ & $2.23 \mathrm{E}-03$ & $3.09 \mathrm{E}-04$ & $6.90 \mathrm{E}-01$ & $1.14 \mathrm{E}-08$ & $1.12 \mathrm{E}-01$ \\
\hline & $1.65 \mathrm{E}-03$ & $5.40 \mathrm{E}-04$ & $7.66 \mathrm{E}-05$ & $1.67 \mathrm{E}-01$ & $5.28 \mathrm{E}-09$ & $2.54 \mathrm{E}-02$ \\
\hline RP/M Ratio & 5.0 & 4.1 & 4.0 & 4.1 & 2.2 & 4.4 \\
\hline \multicolumn{7}{|l|}{ Scenario B } \\
\hline \multirow{2}{*}{$\begin{array}{l}\text { Retail park } \\
\text { Municipal } \\
\text { market }\end{array}$} & $3.66 \mathrm{E}-03$ & $1.36 \mathrm{E}-03$ & 2.38E-04 & $4.03 \mathrm{E}-01$ & $1.19 \mathrm{E}-08$ & 9.64E-02 \\
\hline & $2.50 \mathrm{E}-03$ & 7.43E-04 & $9.25 \mathrm{E}-05$ & $2.20 \mathrm{E}-01$ & 5.29E-09 & $2.80 \mathrm{E}-02$ \\
\hline RP/M Ratio & 1.5 & 1.8 & 2.6 & 1.8 & 2.3 & 3.4 \\
\hline
\end{tabular}

Source: Authors from SimaPro V.7.2 and CML 2000 Methodology

Note: eq=equivalents, $\mathrm{S} b=$ antimony, $\mathrm{SO}_{2}=$ sulfur dioxide, $\mathrm{PO}_{4}{ }^{3-}=$ phosphate, $\mathrm{CO}_{2}=$ carbon dioxide, CFC-11=chlorofluorocarbons, 1,4-DB=1,4-dibuthyl.

\subsubsection{Scenario C: Sustainable policies for customer transport to and from the retail park}

Using the same customer transportation modality distribution for the retail parks as for the municipal markets, the scenario showed a significant reduction $(49 \%)$ of the energy consumption associated with the standard food purchase from 11.1 to $5.8 \mathrm{kWh}$. This decrease represents a $49 \%$ reduction for the environmental impact related to the energy vector, but it remains higher for a retail park than for a municipal market (Table 9) due to the distance of customer travel. 


\begin{tabular}{|c|c|c|c|c|c|c|c|}
\hline & $\begin{array}{c}\text { Energy } \\
\text { consumption } \\
(\mathrm{kWh} / \text { basket })\end{array}$ & $\begin{array}{c}\text { Abiotic } \\
\text { depletion } \\
(\mathrm{kg} \mathrm{Sb} \mathrm{eq})\end{array}$ & $\begin{array}{c}\text { Acidification } \\
\left(\mathrm{kg} \mathrm{SO}_{2} \text { eq }\right)\end{array}$ & $\begin{array}{c}\text { Eutrophication } \\
\left(\mathrm{kg} \mathrm{PO}_{4}{ }^{3-} \text { eq }\right)\end{array}$ & $\begin{array}{c}\text { Global warming } \\
\text { potential } \\
\left(\mathrm{kg} \mathrm{CO}_{2} \mathrm{eq}\right)\end{array}$ & $\begin{array}{c}\begin{array}{c}\text { Ozone layer } \\
\text { depletion }\end{array} \\
\text { (kg CFC-11 eq) }\end{array}$ & $\begin{array}{c}\begin{array}{c}\text { Human } \\
\text { toxicity }\end{array} \\
(\mathrm{kg} 1.4-\mathrm{DB} \text { eq })\end{array}$ \\
\hline \multirow{3}{*}{$\begin{array}{l}\text { Scenario 0 } \\
\text { Retail park } \\
\text { Municipal } \\
\text { market } \\
\end{array}$} & & & & & & & \\
\hline & 11.1 & $2.05 \mathrm{E}-02$ & $1.34 \mathrm{E}-02$ & $1.26 \mathrm{E}-03$ & $3.07 \mathrm{E}+00$ & $3.65 \mathrm{E}-07$ & 7.39E-01 \\
\hline & 0.57 & $1.73 \mathrm{E}-03$ & $1.91 \mathrm{E}-03$ & $1.38 \mathrm{E}-04$ & $2.46 \mathrm{E}-01$ & $2.02 \mathrm{E}-08$ & $6.51 \mathrm{E}-02$ \\
\hline RP/M Ratio & 19.5 & 11.9 & 7.0 & 9.1 & 12.5 & 18.2 & 11.4 \\
\hline $\begin{array}{l}\text { Scenario C } \\
\text { Retail park }\end{array}$ & \multicolumn{6}{|c|}{ Scenario C } & 3.77E-01 \\
\hline $\begin{array}{l}\text { Municipal } \\
\text { market }\end{array}$ & 0.57 & $1.73 \mathrm{E}-03$ & $1.91 \mathrm{E}-03$ & $1.38 \mathrm{E}-04$ & $2.46 \mathrm{E}-01$ & 2.02E-08 & $6.51 \mathrm{E}-02$ \\
\hline RP/M Ratio & 10.2 & 6.2 & 3.6 & 4.7 & 6.4 & 9.2 & 5.8 \\
\hline
\end{tabular}

307 Source: Authors from SimaPro V.7.2 and CML 2000 Methodology

308 Note: eq=equivalents, $\mathrm{Sb}=$ antimony, $\mathrm{SO}_{2}=$ sulfur dioxide, $\mathrm{PO}_{4}{ }^{3-}=$ phosphate, $\mathrm{CO}_{2}=$ carbon dioxide,

$309 \quad$ CFC-11=chlorofluorocarbons, 1,4-DB=1,4-dibuthyl.

\section{Conclusions and improvement proposals}

\subsection{Hypermarket in a retail park}

The transport of customers represents $83.2 \%$ of energy consumption and produces the greatest difference in the energy vector for the two systems of analysis. With this in mind, the managers of such establishments may choose to distribute sustainable mobility policies to their customers to decrease the share of trips in private vehicles and increase the use of public transport. Such a policy could reach a reduction of $49 \%$ of energy consumption and environmental impact per basket. Although these indicators would be still higher for a retail park, the energy vector ratio for retail park to municipal market could be reduced from 20-1 to 10-1 for energy consumption and from 11.7-1 to 6-1, on average, for the other environmental impact categories analyzed.

According to the sensitivity scenarios, current policies for reducing the amount of packaging are focused on consumer packaging, such as the elimination of plastic bags (LDPE), and thus, they result in little positive environmental impact, as relative weight in the total amount of packaging is only $7 \%$. In this sense, waste management policies have to focus more on reducing primary packaging, where the main materials are HDPE and PS, with a 64.6\% of the total weight and the promotion of bulk purchases. The elimination or reduction of materials with greater negative environmental impact, such as polystyrene and PET, also fall under the scope of better waste management practices.

Finally, the environmental impact of energy consumption contributes most to the overall environmental impact, representing $69.7-97.1 \%$ across the different categories. For the retail park hypermarket, the packaging vector has less relevance than energy consumption.

\subsection{Municipal market}

The energy consumption associated to a purchase done in a municipal market is mainly done in the establishment itself $(49.5 \%)$ and in the transportation of workers $(40.4 \%)$. Improvement activities must focus on the market's energy efficiency, amortizing its consumption by increasing commercial surface occupancy and promoting shared use of private vehicles by workers.

At the same time, policies for eliminating plastic bags are relevant to the packaging vector because they represent $25 \%$ of the total packaging weight. Nevertheless, the reduction or elimination of materials, such as polystyrene, with high impact potential on any of the categories analyzed would reduce the impact associated with the vector. The main materials (LDPE, recycled cardboard and plastic paper) have a low impact potential and represent $81.2 \%$ of primary packaging weight. packaging vector represents between the $25-60 \%$ of impacts across categories and the energy vector the $40-75 \%$.

\subsection{Comparison of food retail typologies}

The environmental comparison determines that municipal markets are environmentally better than hypermarkets in retail parks. For the functional unit, the environmental impact is, on average, 10 times higher in a retail park than in a municipal market. In the retail park hypermarket, the related indicators showed energy consumption as 20 times higher and packaging use as 2.5 times higher. Concerning GHG emissions, the associated $\mathrm{CO}_{2}$ equivalent emissions for a standard shopping basket in a retail park are $3.80 \mathrm{~kg}$, or 8 times higher than the emissions rate of a municipal market $353(0.47 \mathrm{~kg})$. 
In the food retail sector, measures to reduce environmental impact need to focus on energy consumption, which contributes $40-75 \%$ in a municipal market and $70-97 \%$ in a retail park hypermarket.

These differences showed that bulk shopping and distances from urban areas are the main differences between the food retail stores analyzed. Therefore, these would be the key points for environmental policies, focusing in the energy efficiency of the buildings, the reduction of distances between the store and the urban areas, and minimizing the packaging amount not only for primary packaging but also for secondary ones. Finally, municipalities' environmental policies should protect the traditional commercial stores situated in the city centre as they showed a better environmental performance than the new type of commercial, like retail parks.

\section{Further research lines}

Future research should focus on applying the concepts of industrial ecology to the service sector and food retail establishments to quantify the flows and better understand the metabolism of the different types of facilities. This kind of analysis would allow the comparison between retail food establishments analyzed here and other facilities in the service sector.

The approach used in this study could be broadened by incorporating the water vector in the metabolism and by designing a different kind of standard shopping basket to determine the main characteristics of different products. This methodology could also be applied in different places in a territorial study that could compare the differences within the same country or between specific countries.

Finally, further research may study the overall stages of the life cycle of agricultural products, from the production stage to waste management and including the distribution stage to develop the relationship between local production and environmental performance.

\section{Acknowledgments}

The authors would like to thank the managers of the municipal markets of Castellar del Vallès, Cerdanyola del Vallès, Olesa de Montserrat and Sant Boi del Llobregat as well as the managers of the retail park in Sant Boi de Llobregat for sharing information. They would also like to thank the Municipal Fairs and Markets Office of the Barcelona County Council for financing the project as part of the "Markets Are Sustainable" campaign.

\section{References}

Andersson, K., Ohlsson, T., Ohlsoon, P., 1998. Screening life cycle assessment (LCA) of tomato ketchup: a case study. Journal of Cleaner Production 6 (3-4), 277 - 288.

Antón, A., Montero, J.I., Muñoz, P., Castells, F., 2005. LCA and tomato production in Mediterranean greenhouses. International Journal of Agricultural Resources Governance and Ecology 4 (2), 102-112.

Ayres, R., Ayres, L., 2001. A handbook of Industrial Ecology. Northampton, MA: Edward Elgar Publication.

Berlin, J., Sonesson, U., Tillman, A.M., 2007. A life cycle based method to minimize environmental impact on dairy production through product sequencing. Journal of Cleaner Production 15, 347 - 356.

Cederberg, C., Mattsson, B., 2000. Life cycle assessment of milk production - a comparison of conventional and organic farming. Journal of Cleaner Production 8 (1), 49-60.

Diputació de Barcelona, 2007. Estudi del impacte econòmic dels mercats municipals de la Diputació de Barcelona [Economic impact study of the municipal markets of the Barcelona Diputation]. Oficina de Mercats i Fires Locals de la Diputació de Barcelona.

Diputació de Barcelona, 2009. Guia de gestió dels residus i de l'energia dels municipal markets [Waste and energy management guide for municipal markets]. Oficina de Mercats i Fires Locals de la Diputació de Barcelona.

Dones, R., Bauer, C., Bolliger, R., Burger, B., Faist Emmenegger, M., Frischknecht, R., Heck, T., Jungbluth, N., Röder, A., Tuchschmid, M., 2007. Life Cycle Inventories of Energy Systems. Results for current Systems in Switzerland and other UCTE Countries. Ecoinvent-Report No 5. Paul Scherrer Institut Villigen, Swiss Centre for Life Cycle Inventories, Dübendorf, $\mathrm{CH}$.

Environmental Eurepean Agency (EEA), 2010 Final energy consumption by sector (CSI 027/ENER 016). Retrieved on December 2010 from <http://www.eea.europa.eu/data-and-maps/indicators/final-energy-consumption-by-sector-1/finalenergy-consumption-by-sector-5>

Erkman, S., 1997. Industrial ecology: An historical view. Journal of Cleaner Production 5 (1-2), 1-10.

Escudero, L.A., 2008. Los centros comerciales. Espacios postmodernos de ocio y consumo. Colección Monografías, n56. Ediciones de la Universidad de Castilla - La Mancha. Cuenca. 
Farreny, R., Gabarrell, X., Rieradevall, J.,2008. Energy intensity and greenhouse gas emission of a purchase in the retail park service sector: An integrative approach. Energy Policy, 36 (6), 1957-1968

Farreny, R., Oliver-Solà, J., Rieradevall, J., Gabarrell., X., 2009. Energy conservation and efficiency in the service sector, in: Utrick, JB (Ed.), Energy and Buildings: Efficiency, Air Quality and Conservation. Nova Science Publishers, Inc., Washington DC, USA, 421-431

Generalitat de Catalunya, 2010a. Anuari 2010. Distribució comercial a Catalunya [2010 Yearbook: Commercial distribution in Catalonia. Àrea de comerç del Departament d'Innovació, Universitats i Empresa.

Generalitat de Catalunya, 2010b. Fitxes detallades dels mercats municipals [Detailed factsheets of municipal markets]. Àrea de comerç del Departament d'Innovació, Universitats i Empresa.

GHG Protocol Initiative, 2005. Calculating CO2 Emissions from Mobile Sources. Retrieved on October 2007 from /http://www.ghgprotocol.orgS.

Graedel, T.E., 1997. Life-cycle assessment in the service industries. Journal of Industrial Ecology 1 (4), 57-70.

Guinée, J.B. (ed.), Gorrée, M., Heijungs, R., Huppes, G., Kleijn, R., de Koning, A., van Oers, L., Wegener Sleeswijk, A., Suh, S., Udo de Haes, H.A., de Bruijn, H., van Duin, R., Huijbregts, M.A.J., Lindeijer, E., Roorda, A.A.H., Weidema, B.P., 2001. Life cycle assessment: an operational guide to the ISO standards. Parts 1 and 2. Ministry of Housing, Spatial Planning and Environment (VROM) and Centre of Environmental Science (CML), Den Haag and Leiden, The Netherlands (Guinée JB, final editor)

Guy, C., 1994. The retail development process. Location, property and planning. Ed. Routledge. Londres. 222 p.

Guy, C., 2006. Retail productivity and land-use planning: negotiating ‘joined-up' retail planning policy. Environment and Planning C: Government and Policy 24 (5), 755-770.

Haberl, H., Fischer-Kowalski, M., Krausmann, F., Weisz, H., Winiwarter, V., 2004. Progress towards sustainability? What the conceptual framework of material and energy flow accounting (MEFA) can offer. Land Use Policy 21(3), 199213.

Heiskanen, E., Jalas, M., 2000. Dematerialization through services. A review and evaluation of the debate. Helsinki: The Finnish Ministry of Environment.

Henningsson, S., Hyde, K., Smith, A., Campbell, M., 2004. The value of resource efficiency in the food industry: a waste minimization project in East Anglia, UK. Journal of Cleaner Production 12 (5), 505-512.

Hischier, R., 2007. Life Cycle Inventories of Packaging and Graphical Papers. Ecoinvent-Report N ${ }^{\circ} 11$, Swiss Centre for Life Cycle Inventories, Dübendorf, 2007.

Hyde, K., Smith, A., Smith, M., Henningsson, S., 2001. The challenge of waste minimization in the food and drink industry: a demonstration project in East Anglia, UK. Journal of Cleaner Production 12 (5), 505 - 512.

Institut d'Estadística de Catalunya (IDESCAT), 2001. Desplaçaments residència-treball. Distribució per professió. Municipis: Sant Boi de Llobregat, Cerdanyola del Vallès, Olesa de Montserrat i Castellar del Vallès. (Place of residence-working place trip. Distribution according professional occupation). Retrieved on January 2010 $<$ http://www.idescat.cat/mobilitat/>

Instituto Nacional de Estadística (INE), 2009. National private vehicle park: Diesel car, Gasoline car and Diesel bus. Retrieved on January 2010 from <http://www.ine.es/ >

International Organization of Standardization (ISO), 2006. 14040. Life cycle assessment—principles and framework. Geneva, Switzerland

Jespersen, J., 1994. Reconciling environment and employment. Switching from goods to services? Paper presented at the Eco-Efficient Services Seminar, Wuppertal Institute, Germany, 1994. As cited in Norgard, J. 1995. Declining efficiency in the economy. Gaia, $5-6$.

Jones, A., 2002. An environmental analysis of food supply chains: a case study on dessert apples. Environmental Management, 30 (4), $560-570$.

Jungbluth, N., Tietje, O., Scholz, R.W., 2000. Food Purchases: Impacts from the Consumers' Point of View Investigated with a Modular LCA. The International Journal of Life cycle Assessment 5 (3), 134 - 142.

Koroneos, C., Roumbas, G., Gabari, Z., Papagiannidou, E., Moussiopoulos, N., 2005. Life cycle assessment of beer production in Greece. Journal of Cleaner Production 9 (1), 57 - 64.

Lundie, S., Peters, G.M., 2005. Life cycle assessment of food waste management options. Journal of Cleaner Production $13(3), 275-286$.

Martínez-Blanco, J., Muñoz, P., Antón, A., Rieradevall, J., 2009. Life cycle assessment of the use of compost from 
municipal organic waste for fertilization of tomato crops. Resources Conservation \& Recycling, 53(6), 340-351

Martínez-Blanco, J., Antón, A., Rieradevall, J., Castellari, M., Pere Muñoz, P. 2011. Comparing nutritional value and yield as functional units in the environmental assessment of horticultural production with organic or mineral fertilization. The case of Mediterranean cauliflower production. The International Journal of Life Cycle Assessment 16 (1), 12-26.

Meisterling, K., Samaras, C., Schweizer, V., 2009. Decisions to reduce greenhouse gases from agriculture and product transport: LCA case study of organic and conventional wheat. Journal of Cleaner Production 17 (2), 222 - 230.

Milà I Canals, L., Cowell, S.J., Sim, S., Basson, L., 2007. Comparin Domestic versus Imported Apples: A focus on energy use. Environmental Science and Pollutant Research 14 (5), 338 - 344.

Morales, A., 2009. Public markets as Community development tools. Journal of Planning Education and Research 28 (4), $426-440$.

Muñoz, P., Antón, A., Montero, J.I., Castells, F., 2004. Using LCA for the improvement of waste management in greenhouse tomato production. In: Proceedings of the Fourth International Conference on Life Cycle Assessment in the Agri-Food Sector, Bygholm, Denmark.

Pinto, J., Carvajal, A., 2003. La dieta equilibrada, prudente o saludable. Colección Nutrición y Salud. Comunidad de Madrid. Instituto de Nutrición y Trastornos Alimentario. Instituto de Salud Pública.

Poritosh, R., Daisuke, N., Orikasa, T., Xu, Q., Okadome, H., 2009. A review of life cycle assessment (LCA) on some food products. Journal of Food Engineering 90 (1), 1 - 10.

Ross, S., Evans, D., 2003. The environmental effect of reusing and recycling a plasticbased packaging system. Journal of Cleaner Production 11 (5), 561 - 571.

World Bank. 2008. World Bank Database. Indicator: Services, etc., value added (\% of GDP) for 2008. Retrieved on November 2010 http://data.worldbank.org/indicator/NV.SRV.TETC.ZS/

Zabaniotou, A., Kassidi, E., 2003. Life cycle assessment applied to egg packaging made from polystyrene and recycled paper. Journal of Cleaner Production 11 (5), 549 - 559. 